\title{
Observations on autoclaved, fumigated and irradiated diets for breeding mice
}

\author{
By G. PORTER AND W. LANE-PETTER \\ MRC Laboratory Animals Centre, Carshalton, Surrey \\ (Received 23 October 1964-Accepted 1o December 1964)
}

How to provide an adequate diet free from common murine pathogens is a problem facing the curators of all pathogen-free animal units. The commercial production of diets suitable for such units has not always been a complete success. There is the difficulty of obtaining complete sterility of the diet and the almost insurmountable obstacle of preventing contamination of the diet from the time it leaves the factory until it is placed before the animal.

\section{EXPERIMENTAL}

\section{Diets}

For the tests we used the following commercially produced diets for rats and mice:

No. I. Dixon's F.F.G. Diet for medical research animals (untreated) (Porter, Lane-Petter \& Horne, r963).

No. 2. Dixon's F.F.G. autoclaved by steam at $120^{\circ}, I_{5} \mathrm{lb} / \mathrm{in}^{2}$ for $\mathrm{I} h$.

No. 3. Dixon's F.F.G. fumigated by ethylene oxide at a gas concentration of I $500 \mathrm{ml} / \mathrm{m}^{3}$ for $6 \mathrm{~h}$.

No. 4. Dixon's F.F.G. sterilized by $\gamma$-irradiation, $2.5 \mathrm{Mrad}$.

No. 5. Dixon's 4I B, Bruce \& Parkes (1956) formula for commercially cubed or pelleted diets (untreated).

No. 6. Dixon's $4 \mathrm{I} B$ autoclaved by steam at $120^{\circ}, I_{5} \mathrm{lb} / \mathrm{in}^{2}$ for $\mathrm{I} h$.

No. 7. Wyatts Chardex (diet I, Porter et al. I963).

No. 8. Wyatts Chardex, autoclaved by steam at $120^{\circ}, 15 \mathrm{lb} / \mathrm{in}^{2}$ for $\mathrm{I} h$.

No. 9. Spillers original laboratory animal diet autoclaved.

No. Io. Spillers autoclaved diet modified.

No. II. Quaker Oats experimental rat and mouse diet.

No. 12. Quaker Oats, experimental diet.

The diets were manufactured and supplied by: nos. I-6, E. Dixon \& Sons, Crane Mead Mills, Ware, Herts; nos. 7 and 8, B. G. Wyatt Limited, Furnham Mills, Chard, Somerset; nos. 9 and ro, Spillers Limited, Old Change House, Cannon Street, London, E.C. 4, and nos. II and I2, Quaker Oats Limited, I39, Park Lane, London, W r.

Table I gives a brief summary of the published vitamin requirements of the mouse.

The values given for diets 9 and ro in Table 2 are the figures stated by the manufacturers, as also is the analysis of diet 12 in Table 3. 
Table 4 shows the effects of autoclaving at $120^{\circ}$ for $\mathrm{I} h$ on the nutrient content of diet $4 \mathrm{I}$ B. Table 5 gives the nutrient content of diet F.F.G. before and after fumigation by ethylene oxide. We are deeply indebted to Dr S. K. Kon and his colleagues, National Institute for Research in Dairying, Shinfield, Reading, and to Dr K. J. Carpenter, School of Agriculture, Cambridge, for providing the values given in these tables.

\section{Table I. Vitamin requirements of the mouse}

\begin{tabular}{|c|c|c|c|c|c|}
\hline \multicolumn{3}{|c|}{ Water-soluble } & \multicolumn{3}{|c|}{ Fat-soluble } \\
\hline Vitamin & $\begin{array}{l}\text { Quantity/kg } \\
\text { food }\end{array}$ & Reference & Vitamin & $\begin{array}{l}\text { Quantity } / \mathrm{kg} \\
\text { food }\end{array}$ & Reference \\
\hline Thiamine & $3 \mathrm{mg}$ & Morris (1947) & A & 300 i.u. & $\begin{array}{l}\text { McCarthy \& } \\
\text { Cerecedo (r953) }\end{array}$ \\
\hline Riboflavine & $\begin{array}{l}\mathrm{I} .5 \mathrm{mg} \\
4.0 \mathrm{mg} \\
4.0-6.0 \mathrm{mg}\end{array}$ & $\begin{array}{l}\text { Morris (1947) } \\
\text { Coward (1952) } \\
\text { Fenton \& } \\
\text { Cowgill (1947) }\end{array}$ & $\mathrm{D}$ & $\begin{array}{l}\text { Not } \\
\text { determined }\end{array}$ & Coward (1952) \\
\hline $\begin{array}{l}\text { Pantothenic } \\
\text { acid }\end{array}$ & $\begin{array}{l}\text { I. } 5 \mathrm{mg} \\
3 \mathrm{mg} \text { as } \mathrm{D}- \\
\text { calcium panto- } \\
\text { thenate }\end{array}$ & $\begin{array}{l}\text { Fenton, Cowgill, } \\
\text { Stone \& Justice } \\
\text { (1950) } \\
\text { Coward (1952) }\end{array}$ & $\mathrm{E}$ & $\begin{array}{l}20 \mathrm{mg} \\
80 \mathrm{mg}\end{array}$ & $\begin{array}{l}\text { Cerecedo \& } \\
\text { Vinson (1944) } \\
\text { Lee, King \& } \\
\text { Visscher ( } 1953 \text { ) }\end{array}$ \\
\hline Vitamin $\mathbf{B}_{12}$ & $\begin{array}{l}5 \mu \mathrm{g} \\
10-20 \mu \mathrm{g}\end{array}$ & $\begin{array}{l}\text { Jaffé (1950) } \\
\text { Bosshart, Paul \& } \\
\text { Barnes (1950) }\end{array}$ & $\mathbf{K}$ & I $\mathrm{mg}$ & $\begin{array}{l}\text { Cuthbertson } \\
(1957)\end{array}$ \\
\hline $\begin{array}{l}\text { Nicotinic } \\
\text { acid (amide) }\end{array}$ & $\begin{array}{l}\text { ro mg; probably } \\
\text { not required } \\
\text { unless diet de- } \\
\text { ficient in trypto- } \\
\text { phan }\end{array}$ & $\begin{array}{l}\text { Cuthbertson } \\
\text { (1957) }\end{array}$ & & & \\
\hline $\begin{array}{l}\text { Pteroyl- } \\
\text { glutamic acid }\end{array}$ & I mg & $\begin{array}{l}\text { Cuthbertson } \\
\text { (1957) }\end{array}$ & & & \\
\hline Biotin & $80 \mu \mathrm{g}$ & $\begin{array}{l}\text { Cuthbertson } \\
\text { (1957) }\end{array}$ & & & \\
\hline Pyridoxine & $\begin{array}{l}\mathrm{I} \mathrm{mg} \\
5 \mathrm{mg}\end{array}$ & $\begin{array}{l}\text { Morris (1947) } \\
\text { Fenton \& } \\
\text { Cowgill (1947) }\end{array}$ & & & \\
\hline $\begin{array}{l}\text { Inositol } \\
\text { Choline }\end{array}$ & $\begin{array}{l}10-100 \mathrm{~g} \\
\mathrm{I} \cdot 0 \mathrm{~g}\end{array}$ & $\begin{array}{l}\text { Wooley (I 94I) } \\
\text { Cuthbertson } \\
\text { (I957) }\end{array}$ & & & \\
\hline
\end{tabular}

Table 2. Manufacturer's stated figures for some components of diets 9-10

Component

Oil (by hydrolysis) (\%)

Vitamin A $(\mu \mathrm{g} / \mathrm{g})$

Vitamin $\mathrm{B}_{2}(\mu \mathrm{g} / \mathrm{g})$

Vitamin $\mathrm{E}(\mu \mathrm{g} / \mathrm{g})$
Diet 9

$6 \cdot 25$

$9 \cdot 15$

$6 \cdot 00$

$9 \cdot 50$
Diet 10

6.55

$9 \cdot 45$

6.95

19.50 


\section{Animals}

Seven strains of inbred mice and six $F_{1}$ crosses from three of these inbred strains were selected to test twelve diets. The inbred strains were $A_{2} G, B A L B / c, C B A$, $\mathrm{C}_{57} \mathrm{BL} / 6, \mathrm{C}_{57} \mathrm{BR} / \mathrm{cd}, \mathrm{DBA} / 2$ and 129 (Dinsley, 196r) subcultivated from the LAC inbred colony (Lane-Petter, I96I). The $F_{1}$ crosses were from $\mathrm{A}_{2} \mathrm{G} \delta \times \mathrm{CBA}$ 웅,

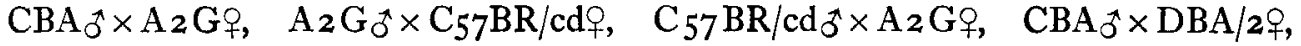
$\mathrm{DBA} / 2 \widehat{0} \times \mathrm{CBA}$.

The method of selection, distribution and mating procedures, as well as the

Table 3. Manufacturer's stated figures for some components of diet $\mathrm{I} 2$

$\begin{array}{lllr} & \% & & \% \\ \text { Protein } & 29.5 & \text { Ash } & 9 \cdot 00 \\ \text { Oil } & 8 \cdot 5 & \text { Carbohydrate } & 42 \cdot 75 \\ \text { Fibre } & 2 \cdot 25 & \text { Moisture } & 8.00\end{array}$

Added minerals (mg/lb)

$\begin{array}{lr}\text { Cobalt } & 0.495 \\ \text { Copper } & 2.500 \\ \text { Manganese } & 2.000 \\ \text { Iodine } & 0.45 \mathrm{r} \\ \text { Zinc } & 2.000 \\ \text { Iron } & 48.500\end{array}$

Added vitamins

$\begin{array}{lr}\text { Vitamin A } & 1250 \\ \text { Vitamin } D_{3} & 177 \\ \text { Riboflavine } & 1 \cdot 0 \\ \text { Thiamine } & 0.4 \mathrm{r} \\ \alpha \text {-Tocopherol } & 22.0 \\ \text { Menaphthone } & 0.27 \\ \text { Pantothenic acid } & 1.08 \\ \text { Choline } & 529 \\ \text { Folic acid } & 0.36 \\ \text { Ascorbic acid } & 1.5 \\ \text { Nicotinic acid } & 6.0 \\ \text { Vitamin } B_{12} & 12.5\end{array}$

Table 4. Effects of autoclaving at $120^{\circ}$ for $\mathrm{I} h$ on the nutrient content of diet 5

\begin{tabular}{|c|c|c|c|}
\hline & $\begin{array}{c}\text { Diet } 5 \\
\text { (untreated) }\end{array}$ & $\begin{array}{c}\text { Diet } 6 \\
\text { (diet } 5 \text { autoclaved) }\end{array}$ & $\begin{array}{l}\text { Diet } 6+16 \mathrm{~g} \\
\text { L-lysine hydro- } \\
\text { chloride } / \mathrm{kg}\end{array}$ \\
\hline \multicolumn{4}{|l|}{ Water-soluble vitamins } \\
\hline Vitamin $B_{12}(\mathrm{ng} / \mathrm{g})$ & $12 \cdot 5$ & $2 \cdot 75$ & 一 \\
\hline Pantothenic acid $(\mu \mathrm{g} / \mathrm{g})$ & $9 \cdot 5$ & $6 \cdot 2$ & 一 \\
\hline Nicotinic acid $(\mu \mathrm{g} / \mathrm{g})$ & $32 \cdot 4$ & $33 \cdot 0$ & - \\
\hline Riboflavine $(\mu \mathrm{g} / \mathrm{g})$ & $3 \cdot 19$ & $2 \cdot 96$ & 一 \\
\hline Pyridoxine hydrochloride $(\mu \mathrm{g} / \mathrm{g})$ & $2 \cdot 43$ & $1 \cdot \mathbf{2 3}$ & - \\
\hline Biotin* (ng/g) & c. 180 & c. 160 & - \\
\hline Thiamine $(\mu \mathrm{g} / \mathrm{g})$ & $4 \cdot 65$ & $1 \cdot 35$ & 一 \\
\hline \multicolumn{4}{|l|}{ Fat-soluble vitamins } \\
\hline Vitamin $\mathrm{A}(\mu \mathrm{g} / \mathrm{l} 00 \mathrm{~g})$ & 77 & 18 & - \\
\hline Carotenes $(\mu \mathrm{g} / \mathrm{r} 00 \mathrm{~g})$ & $8 \cdot 8$ & 8.0 & - \\
\hline$\alpha$-Tocopherol $(\mu \mathrm{g} / \mathrm{i} 00 \mathrm{~g})$ & 1480 & 1100 & - \\
\hline $\begin{array}{l}\text { Comparative nutritive values for } \\
\text { Streptococcus zymogenes }(\text { diet } 5=100)\end{array}$ & 100 & 45 & 55 \\
\hline Available lysine $\dagger$ & $0.62 \%$ & $0.35 \%$ & - \\
\hline
\end{tabular}

* Value is not precise, but there is no significant loss during autoclaving.

$\dagger$ The analysis was carried out by the procedure of Carpenter (1960). Internal recovery tests showed an average recovery of $73.5 \%$ of added DNP-lysine, and the values given are corrected for the same recovery factor. 
technique adopted for housing, caging and handling, were the same as those reported by Porter $e t$ al. I 963 . The parent stocks of the $F_{1}$ crosses were selected from groups of surplus animals of three strains and thereafter treated as inbred animals.

Table 5. Effect of fumigation with ethylene oxide on the nutrient content of diet $\mathbf{I}$

\begin{tabular}{|c|c|c|}
\hline & Nutrie & ontent \\
\hline & $\begin{array}{c}\text { Diet I } \\
\text { (untreated) }\end{array}$ & $\begin{array}{c}\text { Diet } 3 \\
\text { (diet } \mathbf{x} \\
\text { fumigated) }\end{array}$ \\
\hline Biotin $(\mu \mathrm{g} / \mathrm{g})$ & 0.124 & 0.120 \\
\hline Nicotinic acid $(\mu \mathrm{g} / \mathrm{g})$ & $3 x \cdot 7$ & $16 \cdot 0$ \\
\hline Pantothenic acid $(\mu \mathrm{g} / \mathrm{g})$ & $9 \cdot \mathrm{I}$ & IO.3 \\
\hline Riboflavine $(\mu \mathrm{g} / \mathrm{g})$ & $8 \cdot 9$ & $8 \% 9$ \\
\hline Thiamine $(\mu \mathrm{g} / \mathrm{g})$ & $4 \cdot 3$ & $4 \cdot 1$ \\
\hline Vitamin $B_{6}$ (pyridoxine) $(\mu \mathrm{g} / \mathrm{g})$ & $3 \cdot 5^{8}$ & $2 \cdot 75$ \\
\hline Vitamin $\mathbf{B}_{12}(\mu \mathrm{g} / \mathrm{g})$ & 0.026 & 0.032 \\
\hline Folic acid $(\mu \mathrm{g} / \mathrm{g})$ & 0.25 & 0.22 \\
\hline Vitamin $\mathrm{A}(\mu \mathrm{g} / \mathrm{r}$ oo $\mathrm{g})$ & $97^{-5}$ & 120 \\
\hline Carotenes $(\mu \mathrm{g} / \mathrm{L} / 00 \mathrm{~g})$ & 36 & 36 \\
\hline$\alpha$-Tocopherol $(\mu \mathrm{g} / \mathrm{l} 00 \mathrm{~g})$ & 1300 & 1200 \\
\hline$\gamma$-Tocopherol $(\mu \mathrm{g} / \mathrm{l} 00 \mathrm{~g})$ & 950 & 950 \\
\hline Methionine ( $\mathrm{g} / \mathrm{I} 6 \mathrm{~g}$ nitrogen) & $2 * 3$ & $2 \cdot 3$ \\
\hline Histidine ( $\mathrm{g} / \mathrm{I} 6 \mathrm{~g}$ nitrogen) & $I \cdot 4$ & $1 \cdot 2$ \\
\hline $\begin{array}{l}\text { Comparative (untreated diet }=100 \text { ) nutritive } \\
\text { value for Streptococcus zymogenes }\end{array}$ & 100 & 100 \\
\hline Available lysine as $\%$ of the crude protein & 5.04 & $5 \cdot 01$ \\
\hline Crude protein $(\%)$ & 19.5 & $2 I \cdot 2$ \\
\hline
\end{tabular}

Table 6. Breeding performance of an inbred strain of mouse $A_{2} G /$ Lac on three different diets

\begin{tabular}{|c|c|c|c|c|c|c|c|c|}
\hline \multirow{2}{*}{$\begin{array}{l}\text { Diet } \\
\text { no.* }\end{array}$} & \multirow{2}{*}{$\begin{array}{l}\text { No. of } \\
\text { breeding } \\
\text { pairs }\end{array}$} & \multirow{2}{*}{$\begin{array}{c}\text { Mean } \\
\text { prenatal } \\
\text { days } \\
\text { (see below) }\end{array}$} & \multicolumn{3}{|c|}{ Mean no./litter } & \multirow{2}{*}{$\begin{array}{l}\text { Mean total no. } \\
\text { weaned } / 9\end{array}$} & \multirow{2}{*}{$\begin{array}{l}\text { Mean total wt } \\
\text { of young } \\
\text { weaned } / Q(\mathrm{~g})\end{array}$} & \multirow{2}{*}{$\begin{array}{l}Q \text { (see } \\
\text { below) }\end{array}$} \\
\hline & & & Born & Weaned & Lost & & & \\
\hline $\mathbf{I}$ & 20 & 24.9 & $6 \cdot 4$ & $5 \cdot 45$ & 0.95 & 30.05 & $274 \cdot 0$ & $2 I \cdot 9$ \\
\hline 3 & 20 & $28 \cdot 3$ & $7 \cdot 25$ & 6.70 & 0.55 & $28 \cdot 65$ & $264^{\circ} 9$ & 23.7 \\
\hline I0 & 20 & $26 \cdot 5$ & $7 \cdot 50$ & $6 \cdot 75$ & 0.75 & $3 I \cdot 20$ & $256 \cdot 3$ & $25 \cdot 47$ \\
\hline
\end{tabular}

Our criteria for measurement were:

(I) number of prenatal days for female mice monogamously paired for I Io days;

(2) number of young born, number weaned, and the preweaning mortality of the young;

(3) total number of young weaned per breeding pair;

(4) total weight of young weaned per breeding pair;

(5) $Q$, the index of productivity. This is a function of litter size and prenatal interval, that is the time between the first pairing and the birth of the first litter or between the births of successive litters in monogamously mated pairs that are never separated. It is calculated cumulatively from the date of the first pairing to the birth of the last litter and is given as the number of young weaned per 100 prenatal days. (Lane-Petter, Brown, Cook, Porter \& Tuffery, I959). 


\section{RESULTS}

It was impracticable to test every diet on every strain but a large number of comparative tests was made and the results are given below.

\section{Comparison of strains}

Strain $A_{2} G$. This strain was used to test three diets, diet r, diet 3 and diet 10. There was little difference in the results obtained, as is shown by the figures in Table 6. This was one of the few inbred strains that did slightly better on diet Io than on diet I, although the mean total weight weaned per pair was greater on diet I than on diet Io. The physical properties of diet Io may have had some effect on the weaning weight and this is discussed further on p. 304 .

Table 7. Breeding performance of an inbred strain of mouse $B A L B / c L a c$ on three different diets

\begin{tabular}{|c|c|c|c|c|c|c|c|c|}
\hline \multirow{2}{*}{$\begin{array}{l}\text { Diet } \\
\text { no.* }\end{array}$} & \multirow{2}{*}{$\begin{array}{l}\text { No. of } \\
\text { breeding } \\
\text { pairs }\end{array}$} & \multirow{2}{*}{$\begin{array}{c}\text { Mean } \\
\text { prenatal } \\
\text { days } \\
\text { (see p. 298) }\end{array}$} & \multicolumn{3}{|c|}{ Mean no./litter } & \multirow{2}{*}{$\begin{array}{c}\text { Mean total no. } \\
\text { weaned/ } 9\end{array}$} & \multirow{2}{*}{$\begin{array}{c}\text { Mean total wt } \\
\text { of young } \\
\text { weaned } / \mathrm{g}(\mathrm{g})\end{array}$} & \multirow[b]{2}{*}{$Q$} \\
\hline & & & Born & Weaned & Lost & & & \\
\hline I & 20 & $27 \cdot 85$ & 6.05 & 5.55 & 0.5 & $24 \cdot 2$ & $228 \cdot 7$ & 19.92 \\
\hline 9 & 20 & $29 \cdot 3$ & $7 \cdot 0$ & 5.9 & $I \cdot I$ & $25 \cdot 4$ & 210.8 & $20 \cdot 13$ \\
\hline 10 & 20 & 30.9 & $5 \cdot 15$ & $4 \cdot 25$ & 0.9 & $17 \cdot 3$ & 150.3 & I3.75 \\
\hline
\end{tabular}

Table 8. Breeding performance of an inbred strain of mouse CBA/Lac on twelve different diets

\begin{tabular}{|c|c|c|c|c|c|c|c|c|c|}
\hline \multirow[b]{2}{*}{$\begin{array}{l}\text { Diet } \\
\text { no.* }\end{array}$} & \multirow{2}{*}{$\begin{array}{l}\text { No. of } \\
\text { breeding } \\
\text { pairs }\end{array}$} & \multirow{2}{*}{$\begin{array}{c}\text { Mean } \\
\text { prenatal } \\
\text { days } \\
\text { (see p. 298) }\end{array}$} & \multicolumn{3}{|c|}{ Mean no./litter } & \multirow{2}{*}{$\begin{array}{l}\text { Mean } \\
\text { total no. } \\
\text { weaned } / \text { ? }\end{array}$} & \multirow{2}{*}{$\begin{array}{c}\text { Mean total } \\
\text { wt of young } \\
\text { weaned/P (g) }\end{array}$} & \multirow{2}{*}{$\begin{array}{c}\text { Mean } \\
\text { weaning } \\
\text { wt of } \\
\text { young }\end{array}$} & \multirow[b]{2}{*}{$Q$} \\
\hline & & & Born & Weaned & Lost & & & & \\
\hline $\mathbf{I}$ & 20 & $23 \cdot 75$ & $7 \cdot 5$ & 6.8 & 0.7 & $29 \cdot 35$ & $218 \cdot 63$ & $7 \cdot 44$ & $28 \cdot 63$ \\
\hline 2 & 20 & $26 \cdot 35$ & $7 \cdot 5$ & $6 \cdot 85$ & 0.65 & 30.9 & $225 \cdot 65$ & $7 \cdot 30$ & 25.99 \\
\hline 3 & 20 & $27 \cdot 65$ & $6 \cdot 75$ & $6 \cdot 0$ & 0.75 & $26 \cdot 12$ & 207.85 & $7 \cdot 95$ & $2 I \cdot 69$ \\
\hline 4 & 20 & $26 \cdot 85$ & $7 \cdot 35$ & $6 \cdot 3$ & $I \cdot 05$ & $27 \cdot 95$ & 205.20 & $7 \cdot 34$ & 23.46 \\
\hline 5 & 20 & $25 \cdot 75$ & $6 \cdot 8$ & 5.45 & $\mathrm{I} \cdot 35$ & $25 \cdot 0$ & $I 86 \cdot 14$ & $7 \cdot 44$ & $2 I \cdot I 6$ \\
\hline 6 & 20 & 30.6 & $6 \cdot 0$ & $5 \cdot 25$ & 0.75 & $21 \cdot 5$ & I 53.44 & $7 \cdot 13$ & $17 \cdot 15$ \\
\hline 7 & 20 & $29 \cdot 65$ & $7 \cdot 35$ & $6 \cdot 25$ & $I \cdot I$ & $26 \cdot 2$ & $188 \cdot 45$ & $7 \cdot 19$ & $2 I \cdot 08$ \\
\hline 8 & 20 & $28 \cdot 5$ & $7 \cdot 5$ & $6 \cdot 9$ & 0.6 & $29 \cdot 8$ & 230.55 & $7 \cdot 73$ & 24.21 \\
\hline 9 & 20 & $27 \cdot 5$ & $6 \cdot 5$ & $5 \cdot 2$ & $1 \cdot 3$ & $2 I \cdot 6$ & 149.0 & $6 \cdot 89$ & 18.90 \\
\hline I0 & 20 & 27.0 & $5 \cdot 5$ & 3.85 & $\mathrm{I} \cdot 65$ & 17.05 & I 8.2 & 6.93 & 14.25 \\
\hline I I & 20 & $3 I \cdot 45$ & $6 \cdot 4$ & 6.0 & 0.4 & $22 \cdot 35$ & 190.2 & $8 \cdot 5^{x}$ & 19.07 \\
\hline 12 & 20 & $32 \cdot 3$ & $7 \cdot 0$ & 4.9 & $2 \cdot 1$ & 19.2 & I $48 \cdot 55$ & $7 \cdot 73$ & r5.17 \\
\hline
\end{tabular}

* I, F.F.G.; 2, F.F.G. autoclaved; 3, F.F.G. fumigated; 4, F.F.G. irradiated; 5, 4I B; 6, 4I B autoclaved; 7, Chardex; 8, Chardex autoclaved; 9, Spillers original; Io, Spillers modified; 1 I, Quaker Oats; 12, Quaker S.P.F.

Strain $B A L B / c$. Diets 1,9 and Io were tested. Table 7 shows that diets $\mathrm{I}$ and 9 were almost equal, both being considerably better than diet Io. The mean total weight of young weaned was greater on diet I than on diets 9 or ro, which suggests that young inbred mice cannot deal effectively with the physical properties of some of these diets. 
Strain $C B A$. Porter et al. (1963) found that this inbred strain was a sensitive indicator for assessing the adequacy of so-called standard diets. We did, therefore, test all twelve diets on this strain of mouse.

In order to make the comparisons reasonably simple, we have divided the diets into four groups and given a rank analysis of each group in Table 8. The results obtained from the four untreated diets confirm our earlier work (Porter et al. 1963) in which we found that F.F.G. (diet I) was the best British commercial diet for this strain of mouse.

The breeding performance on F.F.G. sterilized by three methods, i.e. diet 2 autoclaved by steam, diet 3 fumigated by ethylene oxide and diet 4 sterilized by $\gamma$ irradiation at $2.5 \mathrm{Mrad}$, shows that the autoclaved diet gave the best results. The number of prenatal days was less with this diet than with the other two, and the other relevant criteria showed diet 2 to be better than diet 3 or diet 4 .

Table 9. Breeding performance of an inbred strain of mouse $C_{57} B R / c d L a c$ on three different diets

\begin{tabular}{|c|c|c|c|c|c|c|c|c|}
\hline \multirow{2}{*}{$\begin{array}{l}\text { Diet } \\
\text { no.* }\end{array}$} & \multirow{2}{*}{$\begin{array}{l}\text { No. of } \\
\text { breeding } \\
\text { pairs }\end{array}$} & \multirow{2}{*}{$\begin{array}{c}\text { Mean } \\
\text { prenatal } \\
\text { days } \\
\text { (see p. 298) }\end{array}$} & \multicolumn{3}{|c|}{ Mean no./litter } & \multirow{2}{*}{$\begin{array}{c}\text { Mean } \\
\text { total no. } \\
\text { weaned } / Q \text {. }\end{array}$} & \multirow{2}{*}{$\begin{array}{c}\text { Mean total } \\
\text { wt of young } \\
\text { weaned }(\mathrm{g})\end{array}$} & \multirow[b]{2}{*}{$Q$} \\
\hline & & & Born & Weaned & Lost & & & \\
\hline I & 20 & $39 \cdot 5$ & $7 \cdot 4$ & $5 \cdot 45$ & I.95 & I $8 \cdot 9$ & $132 \cdot 3$ & I3.79 \\
\hline 9 & 20 & $52 \cdot 5$ & 6.4 & 0.8 & $5 \cdot 6$ & 30 & 10.3 & 0.15 \\
\hline IO & 20 & $38 \cdot 2$ & $7^{7} \mathrm{I}$ & $5 \cdot 15$ & I'95 & 17.55 & II 8.6 & 13.48 \\
\hline
\end{tabular}

Table Iо. Breeding performance of an inbred strain of mouse $C_{57} B L / 6 L a c$

\begin{tabular}{|c|c|c|c|c|c|c|c|c|}
\hline \multirow{2}{*}{$\begin{array}{l}\text { Diet } \\
\text { no.* }\end{array}$} & \multirow{2}{*}{$\begin{array}{c}\text { No. of } \\
\text { breeding } \\
\text { pairs }\end{array}$} & \multirow{2}{*}{$\begin{array}{c}\text { Mean } \\
\text { prenatal } \\
\text { days } \\
\text { (see p. 298) }\end{array}$} & \multicolumn{3}{|c|}{ Mean no./litter } & \multirow{2}{*}{$\begin{array}{c}\text { Mean } \\
\text { total no. } \\
\text { weaned } / \text { ? }\end{array}$} & \multirow{2}{*}{$\begin{array}{c}\text { Mean total } \\
\text { wt of young } \\
\text { weaned } / q(\mathrm{~g})\end{array}$} & \multirow[b]{2}{*}{$Q$} \\
\hline & & & Born & Weaned & Lost & & & \\
\hline $\mathbf{I}$ & 30 & $27 \cdot 9$ & $6 \cdot 4$ & $5 \cdot 45$ & 0.95 & $21 \cdot 4$ & $165 \cdot 9$ & 19.53 \\
\hline 3 & 30 & $32 \cdot 05$ & $6 \cdot I$ & $5 \cdot 6$ & 0.5 & $20 \cdot 8$ & 154.4 & $17 \cdot 47$ \\
\hline 10 & 30 & $3^{8 \cdot 55}$ & 5.8 & 47 & $1 \cdot I$ & I 4.45 & $106 \cdot 85$ & 12.19 \\
\hline 12 & 30 & $52 \cdot 45$ & $5 \cdot 85$ & 5.25 & 0.6 & $15 \cdot 25$ & 113.7 & 10.00 \\
\hline
\end{tabular}

The figures given for the three commercial diets that were steam-autoclaved show that diet 2 (F.F.G.) was better than diet 8 (Chardex), both being superior to diet 6 (4I B).

Diets 9,10 and 12 all appeared to be unsatisfactory for this strain of mouse. The preweaning loss per litter was high, especially on diet $\mathbf{1 2}$, and the numbers born per litter on diet 10 were considerably lower than for any of the other diets. Diet 12 also gave uneconomically long prenatal periods.

Strain $C_{57} B R / c d$. M. Dinsley (1964, personal communication) found that it was necessary to provide this strain with supplements when fed on diet I. Table 9 shows that diets $I$ and ro were suboptimal and that diet 9 was grossly inadequate. It again suggests that the physical properties of diets 9 and Io were partly responsible for the poor reproductive performance. The high preweaning mortality indicated that the 
young mice were unable to manipulate these hard cubes. The figures for diets 9 and ro show a complete reversal of those obtained for the other strains. This is a further indication that feeding inbred strains of mice is a more complex problem than feeding non-inbred strains.

Table I I. Breeding performance of an inbred strain of mouse $C_{57} B L / 6 \mathrm{Lac}$ on three different diets, showing a decline in the and generation

\begin{tabular}{|c|c|c|c|c|c|c|c|c|c|}
\hline \multirow{2}{*}{$\begin{array}{l}\text { Diet } \\
\text { no. }\end{array}$} & \multirow[b]{2}{*}{ Generation } & \multirow{2}{*}{$\begin{array}{l}\text { No. of } \\
\text { breeding } \\
\text { pairs }\end{array}$} & \multirow{2}{*}{$\begin{array}{c}\text { Mean } \\
\text { prenatal } \\
\text { days } \\
\text { (see p. 298) }\end{array}$} & \multicolumn{3}{|c|}{ Mean no./litter } & \multirow{2}{*}{$\begin{array}{l}\text { Mean } \\
\text { total no. } \\
\text { weaned/P }\end{array}$} & \multirow{2}{*}{$\begin{array}{c}\text { Mean total } \\
\text { wt of young } \\
\text { weaned/? }(\mathrm{g})\end{array}$} & \multirow[b]{2}{*}{$Q$} \\
\hline & & & & Born & Weaned & Lost & & & \\
\hline I & Ist & 15 & $26 \cdot I$ & $6 \cdot 1$ & $5 \cdot 2$ & 0.9 & $21 \cdot 8$ & $172 \cdot 2$ & 19.92 \\
\hline Io & & 15 & $28 \cdot 5$ & 5.8 & $4 \cdot 9$ & 0.9 & 18.8 & $141 \cdot 0$ & $17 \cdot 19$ \\
\hline 12 & & 15 & 35.5 & $6 \cdot 6$ & $6 \cdot 3$ & 0.3 & $20 \cdot 2$ & 165.6 & 17.74 \\
\hline I & 2nd & 15 & $29 \cdot 7$ & $6 \cdot 7$ & $5 \cdot 7$ & $1 \cdot 0$ & $21 \cdot 0$ & $159 \cdot 6$ & 19.19 \\
\hline IO & & 15 & $48 \cdot 6$ & $5 \cdot 8$ & $4 \cdot 5$ & $r \cdot 3$ & IO.I & $72 \cdot 7$ & 9.25 \\
\hline I2 & & 15 & $69 \cdot 4$ & $5 \cdot 1$ & $4 \cdot 2$ & 0.9 & 10.3 & $61 \cdot 8$ & 6.05 \\
\hline
\end{tabular}

Table 12. Breeding performance of an inbred strain of mouse $\mathrm{I} 29 / \mathrm{Lac}$ on three different diets

\begin{tabular}{|c|c|c|c|c|c|c|c|c|}
\hline \multirow{2}{*}{$\begin{array}{l}\text { Diet } \\
\text { no.* }\end{array}$} & \multirow{2}{*}{$\begin{array}{l}\text { No. of } \\
\text { breeding } \\
\text { pairs }\end{array}$} & \multirow{2}{*}{$\begin{array}{c}\text { Mean } \\
\text { prenatal } \\
\text { days } \\
\text { (see p. 298) }\end{array}$} & \multicolumn{3}{|c|}{ Mean no./litter } & \multirow{2}{*}{$\begin{array}{c}\text { Mean } \\
\text { total no. } \\
\text { weaned/q }\end{array}$} & \multirow{2}{*}{$\begin{array}{c}\text { Mean total } \\
\text { wt of young } \\
\text { weaned/q }(\mathrm{g})\end{array}$} & \multirow[b]{2}{*}{$Q$} \\
\hline & & & Born & Weaned & Lost & & & \\
\hline I & 20 & $27 \cdot 75$ & 5 . & 5. & 0.6 & 24.5 & $221 \cdot 0$ & $19 \cdot 22$ \\
\hline 2 & 20 & 37.40 & $6 \cdot 25$ & 5 . & 0.85 & 19.05 & 162.5 & 14.43 \\
\hline 9 & 20 & 78.0 & 3.7 & $2 \cdot 7$ & $1 \cdot 0$ & $6 \cdot 2$ & $45 \cdot 8$ & $3 \cdot 4$ \\
\hline
\end{tabular}

Strain $C_{57} B L / 6$. The four diets tested on this strain were diets I, 3, I0 and 12 . This strain does not normally have a high figure for $Q$. The results we obtained with diets I and 3 were average for this mouse. Diets $\mathrm{I} O$ and $\mathbf{I} 2$ appeared to be grossly inadequate, as is shown in Table ro. We have confirmed (Table II) the advantage of using an inbred strain of mouse to test the adequacy of diets. The first generation of animals on diets 10 and 12 appeared to show reasonable results, but the second generation clearly showed the inadequacy of these diets for this strain (diet I was included in this table for comparison).

Strain $D B A / 2$. M. Dinsley (1964, personal communication) found that productivity was abnormally low in this inbred strain; it was, therefore, considered unsuitable for testing diets. Nevertheless, any inbred strain may have to be maintained, and it is essential to find a diet suitable for all such strains. Diet to was tested, and it was found that there was a significant lowering of the number weaned in the second generation. The mean number of young weaned per breeding pair was $5.6 / 100$ prenatal days. Further observations with this strain of mouse had to be abandoned because of the poor condition of the few animals weaned in the second generation.

Strain 129. Diets I, 2 and 9 were tested. Table I2 gives the results obtained. Diet I appeared to be adequate, but diet 2 considerably increased the number of 
prenatal days, thereby reducing the number of young weaned per breeding pair and the figure for $Q$. Diet 9 was found to be inadequate.

$F_{1}$ crosses. The ability of $F_{1}$ crosses to utilize a diet that had been found inadequate for some of the parent strains is shown in Tables $13-15$. The relevant information for the parent strains has been included in these tables in order to simplify comparisons.

Strain $\mathrm{A}_{2} \mathrm{G}$ did better on diet ro than any of the other strains, but $\mathrm{C}_{57} \mathrm{BR} / \mathrm{cd}$ gave a poor breeding performance. The $F_{1}$ crosses of these two strains did well on diet Io, as shown in Table ${ }_{2}$. When the female parent was $\mathrm{A}_{2} \mathrm{G}$ the results were slightly better than when the female was $\mathrm{C}_{57} \mathrm{BR} / \mathrm{cd}$. This is further demonstrated in Table $\mathrm{I}_{3}$, where it is shown that one of the parent strains $\mathrm{A}_{2} \mathrm{G}$ was better than the other parent strain, CBA. The $F_{1}$ crosses did better when the female of the parent strain was $\mathrm{A}_{2} \mathrm{G}$. In Table $\mathrm{I}_{4}$ it is seen that $F_{1}$ crosses between CBA and $\mathrm{DBA} / 2$ gave good results, although both parent strains did poorly.

Table I3. Comparisons between the breeding performance of parent strains $A_{2} G$ and $C_{57} B R / c d$ and their $F_{1}$ crosses on diet ro (Spillers modified)

\begin{tabular}{|c|c|c|c|c|c|c|c|c|}
\hline \multirow[b]{2}{*}{ Strain } & \multirow{2}{*}{$\begin{array}{l}\text { No. of } \\
\text { breeding } \\
\text { pairs }\end{array}$} & \multirow{2}{*}{$\begin{array}{l}\text { Mean } \\
\text { prenatal } \\
\text { days } \\
\text { (see } \\
\text { p. 298) }\end{array}$} & \multicolumn{3}{|c|}{ Mean no./litter } & \multirow{2}{*}{$\begin{array}{c}\text { Mean } \\
\text { total no. } \\
\text { weaned } / ?\end{array}$} & \multirow{2}{*}{$\begin{array}{c}\text { Mean total } \\
\text { wt of young } \\
\text { weaned/o }(g)\end{array}$} & \multirow[b]{2}{*}{$Q$} \\
\hline & & & Born & Weaned & Lost & & & \\
\hline$A_{2} G$ & 20 & $26 \cdot 5$ & $7 \cdot 50$ & 6.75 & 0.75 & $3 I \cdot 20$ & $256 \cdot 3$ & $25 \cdot 47$ \\
\hline $\mathrm{C}_{57} \mathrm{BR} / \mathrm{cd}$ & 20 & $38 \cdot 2$ & $7 \cdot 1$ & 5.15 & I.95 & $17 \cdot 55$ & I I $8 \cdot 6$ & $13 \cdot 48$ \\
\hline$F_{1}\left(\mathrm{~A}_{2} \mathrm{G}_{0} \times \mathrm{C}_{57} \mathrm{BR}\right.$ ) $)$ & 20 & $24 \cdot 95$ & $9 \cdot 85$ & $9 \cdot 25$ & 0.6 & $42 \cdot 5$ & $382 \cdot 0$ & 37.07 \\
\hline$F_{1}\left(\mathrm{C}_{57} \mathrm{BR}_{\delta} \times \mathrm{A}_{2} \mathrm{G}_{+}\right)$ & 20 & $24 \cdot 3$ & $\mathbf{I} \mathbf{I} \cdot \mathbf{2}$ & 10.0 & $1 \cdot 2$ & $51 \cdot 5$ & $473 \cdot 8$ & $4 I \cdot I 5$ \\
\hline
\end{tabular}

Table 14. Comparisons between the breeding performance of parent strains $A_{2} G$ and $C B A$ and their $F_{1}$ crosses on diet ro (Spillers modified)

\begin{tabular}{|c|c|c|c|c|c|c|c|c|}
\hline \multirow[b]{2}{*}{ Strain } & \multirow{2}{*}{$\begin{array}{l}\text { No. of } \\
\text { breeding } \\
\text { pairs }\end{array}$} & \multirow{2}{*}{$\begin{array}{c}\text { Mean } \\
\text { prenatal } \\
\text { days } \\
\text { (see } \\
\text { p. } 298)\end{array}$} & \multicolumn{3}{|c|}{ Mean no./litter } & \multirow{2}{*}{$\begin{array}{c}\text { Mean } \\
\text { total no. } \\
\text { weaned/o }\end{array}$} & \multirow{2}{*}{$\begin{array}{c}\text { Mean total } \\
\text { wt of young } \\
\text { weaned/o }(\mathrm{g})\end{array}$} & \multirow[b]{2}{*}{$Q$} \\
\hline & & & Born & Weaned & Lost & & & \\
\hline $\mathrm{A}_{2} \mathrm{G}$ & 20 & $26 \cdot 5$ & $7 \cdot 50$ & $6 \cdot 75$ & 0.75 & $31 \cdot 20$ & $256 \cdot 3$ & 25.47 \\
\hline CBA & 20 & $27 \cdot 0$ & $5 \cdot 5$ & $3 \cdot 85$ & $1 \cdot 65$ & $17 \cdot 05$ & I $8 \cdot 2$ & 14.25 \\
\hline$F_{1}\left(\mathrm{~A}_{2} \mathrm{G}_{\hat{O}} \times \mathrm{CBA}\right.$ ) & 20 & $26 \cdot 9$ & 9.0 & $8 \cdot 4$ & 0.6 & $36 \cdot 0$ & $338 \cdot 4$ & $3 I \cdot 22$ \\
\hline$F_{1}\left(\mathrm{CBA} \hat{0} \times \mathrm{A}_{2} \mathrm{GO}\right)$ & 20 & $23 \cdot 8$ & 10.8 & $9 \cdot 8$ & $I \cdot 0$ & $47 \cdot 0$ & 470.0 & $4 I \cdot 17$ \\
\hline
\end{tabular}

Table I 5. Comparisons between the breeding performance of parent strains $C B A$ and $D B A / 2$ and their $F_{1}$ crosses on diet ro (Spillers modified)

\begin{tabular}{|c|c|c|c|c|c|c|c|c|}
\hline \multirow[b]{2}{*}{ Strain } & \multirow{2}{*}{$\begin{array}{l}\text { No. of } \\
\text { breeding } \\
\text { pairs }\end{array}$} & \multirow{2}{*}{$\begin{array}{l}\text { Mean } \\
\text { prenatal } \\
\text { days } \\
\text { (see } \\
\text { p. } 298 \text { ) }\end{array}$} & \multicolumn{3}{|c|}{ Mean no./litter } & \multirow{2}{*}{$\begin{array}{c}\text { Mean } \\
\text { total no. } \\
\text { weaned/? }\end{array}$} & \multirow{2}{*}{$\begin{array}{c}\text { Mean total } \\
\text { wt of young } \\
\text { weaned/f }(\mathrm{g})\end{array}$} & \multirow[b]{2}{*}{$Q$} \\
\hline & & & Born & Weaned & Lost & & & \\
\hline CBA & 20 & $27 \cdot 0$ & $5 \cdot 5$ & $3 \cdot 85$ & $1 \cdot 65$ & 17.05 & $\operatorname{II} 8 \cdot 2$ & I4.25 \\
\hline $\mathrm{DBA} / 2$ & 20 & $35^{\circ} 0$ & $4 \cdot 6$ & 3.65 & 0.95 & 9.85 & 69.28 & 10.25 \\
\hline$F_{1}(\mathrm{CBA} \precsim \times \mathrm{DBA} / 2+)$ & 20 & $22 \cdot 8$ & $9 \cdot 0$ & $8 \cdot 0$ & 1.0 & $37 \cdot 5$ & $337 \cdot 5$ & 35.08 \\
\hline$F_{1}(\mathrm{DBA} / 2 \sigma \times \mathrm{CBA}+)$ & 20 & $24 \cdot 1$ & $8 \cdot 7$ & $8 \cdot I$ & 0.6 & $39 \cdot 1$ & $332: 3$ & $33 \cdot 60$ \\
\hline
\end{tabular}




\section{Comparison of diets}

Untreated commercial diets. Diet I (F.F.G.) gave better results than the other three diets tested. There was little difference between diet 5 (4I B) and diet 7 (Chardex). Diet I I (Quaker) was the poorest for the strains of mouse tested. Diet I was unsatisfactory for strain $\mathrm{C}_{57} \mathrm{BR} / \mathrm{cd}$.

Autoclaved commercial diets. Diet 2 (F.F.G.) and diet 8 (Chardex) gave equally good results for the CBA strain of mouse and were superior to diet 6 (4I B). A supplement of lysine $(0.33 \%, \mathrm{w} / \mathrm{w})$ was far from effective in restoring the nutritive value of the autoclaved diet. On diet 2 , strain 129 had a considerably higher number of prenatal days and a low figure for $Q$.

Diet F.F.G. treated by autoclaving, fumigation and irradiation. Diets 2, 3 and 4 all gave good results. Diet 2, (autoclaved) gave better results than diet 4 (irradiated), and for CBA mice both were better than diet 3 (fumigated). Strain $A_{2} G$ did equally well on diets $I$ and 3 (F.F.G. before and after fumigation).

Diets recommended as pathogen-free. For strain CBA, diet 9 (Spillers original) gave the best results. There was little difference between diets Io (Spillers modified) and I2 (Quaker experimental). The mean weaning weights of the young were greater on diet I 2 than on diets 9 and ro, on which they were equal. Strain BALB/c did better on diet 9 than on diet 10 . The mean weaning weight of the young was $1 \mathrm{~g} /$ mouse better on diet r (F.F.G.) than on diets 9 and $x$. Diet 9 was inadequate for strains $\mathrm{C}_{57} \mathrm{BR} / \mathrm{cd}$, $\mathrm{C}_{57} \mathrm{BL} / 6$ and 129 . Diet 10 was inadequate for $\mathrm{C}_{57} \mathrm{BR} / \mathrm{cd}, \mathrm{C}_{57} \mathrm{BL} / 6$ and DBA/2, but gave excellent results with all $F_{1}$ hybrids. Diet 12 was inadequate for $\mathrm{C}_{57} \mathrm{BL} / 6$.

\section{Possible hazards of diets treated with ethylene oxide}

Diets treated with ethylene oxide may have toxic effects under certain conditions. We accidentally killed a number of animals by feeding them on a treated diet that had been stored at about $6^{\circ}$ after being removed from the fumigation chamber. Three strains of breeding mice, i.e. $\mathrm{CBA}, \mathrm{A}_{2} \mathrm{G}$ and $\mathrm{C}_{57} \mathrm{BL} / 6$, were fed on the toxic diet. None of the males were affected, nor were the females of strain $\mathrm{C}_{57} \mathrm{BL} / 6$, but $50 \%$ of $\mathrm{CBA}$ and $33 \%$ of $\mathrm{A}_{2} \mathrm{G}$ lactating females died within $48 \mathrm{~h}$ of receiving the diet. The effects of this diet on two inbred strains of mice 19-28 days of age is shown below.

$\begin{array}{lcccc}\text { Strain } & \text { Sex } & \begin{array}{c}\text { No. of } \\ \text { animals }\end{array} & \text { No. } & \% \\ \mathrm{CBA} & 0 & 52 & 31 & 59 \cdot 6 \\ & 9 & 59 & 23 & 38 \cdot 9 \\ \mathrm{~A} 2 \mathrm{G} & + & 2 \mathrm{I} & 12 & 57 \cdot 2 \\ & 0 & 24 & 7 & 40.5\end{array}$

DISCUSSION

Comparison of growth and reproduction shows that the feeding of inbred strains of mice presents more problems than the feeding of non-inbred strains or $F_{1}$ crosses of inbred strains.

Steam autoclaving of commercially produced diets in order to produce a sterile 
diet inevitably causes some damage to the constituents, but the results reported here suggest that one type of diet may suffer less from autoclaving than another. If autoclaving is unavoidable, consideration must be given to the raw ingredients of the diet.

The effects of an unpalatable diet on breeding and lactating animals cannot be completely ignored. Autoclaved diets are less palatable than non-autoclaved; diets fumigated by ethylene oxide have an obnoxious smell and a somewhat bitter taste. When a group of mice was given the choice between an untreated diet and the same diet fumigated by ethylene oxide, they always chose the untreated.

Some of the results could have been affected by palatability and not by a deficiency of nutrients.

The toxic effects of ethylene oxide appeared to affect the young males more than the young females. In the breeding stock, however, it affected only the lactating females of two strains, $\mathrm{A}_{2} \mathrm{G}$ and $\mathrm{CBA}$; the $\mathrm{C}_{57} \mathrm{BL} / 6$ strain and the males of $\mathrm{A}_{2} \mathrm{G}$ and $\mathrm{CBA}$ were not affected. The higher percentage of deaths in young males and lactating females may have been connected with the higher metabolic rate of young males than of females, and of lactating females than of adult males. A small group of CBA mice of both sexes being kept for a longevity test was not affected.

We have since kept the diet treated with ethylene oxide at $21^{\circ}$ and have had no further losses. We continue to investigate the effect of diets treated with ethylene oxide on strains $A_{2} G$ and CBA. At the time of writing both strains are in the fourth generation, but owing to our method of random selection these two strains can no longer be referred to as inbred. We are continuing tests of diet F.F.G. sterilized by $\gamma$-irradiation.

The difference between hardness of a cube and what may be described as 'gnawability' is a subtle one. A hard gnawable cube is acceptable to most mice and rats (even very young ones), but an equally hard ungnawable one is unacceptable. A cube with a high nutritional value is useless if the animals cannot eat it, and this is demonstrated in Table 8 . The weaker inbred strains appeared to be incapable of dealing with diet ro, whereas the robust hybrids could. The special diets for pathogen-free animals were unsatisfactory for inbred strains of mice, but adequate for their $F_{1}$ crosses.

\section{SUMMARY}

I. Commercially produced diets before and after sterilization by autoclaving, fumigation or irradiation were studied for their effects on the breeding performance of inbred strains of mice. The animals were mated in monogamous pairs, remaining together for I Io days, during which time their prenatal days, litter size, preweaning loss, numbers weaned and the weaning weight of the young were recorded.

2. It has been shown that one commercial diet (F.F.G.) was superior to the other diets tested, and it was further shown that this diet when autoclaved supported reproduction, lactation and growth better than did the other two autoclaved diets.

3. Irradiation and fumigation were both found to be acceptable methods of sterilization, and fumigation used in the prescribed manner did not give rise to toxicity.

4. The physical properties of a diet had an important bearing on its efficiency. 
We thank Mr F. J. Ley, United Kingdom Atomic Energy Authority, Wantage Radiological Laboratories, Berks., for irradiating diet 4, Mr J. Izard for technical assistance and Mr David Chanry for care of the animals.

\section{REFERENCES}

Bosshart, D. K., Paul, W. G. \& Barnes, R. H. (1950). F. Nutr. 40, 595.

Bruce, H. M. \& Parkes, A. S. (1956). F. Anim. Tech. Ass. 7, 54.

Carpenter, K. J. (1960). Biochem. F. 77, 604.

Cerecedo, L. R. \& Vinson, L. J. (1944). Fed. Proc. 3, 55.

Coward, K. H. (1952). Vitamin Requirements of Different Species of Laboratory Animal. Laboratory Animals Bureau Technical Note no. I (Mimeo).

Cuthbertson, W. F. J. (1957). Lab. Anim. Cent. coll. Pap. 5, 27.

Dinsley, M. (1961). Mouse News Lett. 25, Comp. Issue, no. 2, p. 37.

Fenton, P. F. \& Cowgill, G. R. (1947). F. Nutr. 34, 273.

Fenton, P. F., Cowgill, G. R., Stone, M. A. \& Justice, D. H. (1950). F. Nutr. 42, 257.

Jaffé, W. G. (1950). Arch. Biochem. 27, 464.

Lane-Petter, W. (196I). Provision of Laboratory Animals for Research: A Practical Guide. Amsterdam: Elsevier Publ. Co.

Lane-Petter, W., Brown, A. M., Cook, M. J., Porter, G. \& Tuffery, A. A. (1959). Nature, Lond., r83, 339.

Lee, Y. C. P., King, J. T. \& Visscher, M. B. (1953). Amer. F. Physiol. 173, 456.

McCarthy, P. T. \& Cerecedo, L. R. (1953). F. Nutr. 49, 357.

Morris, H. P. (1947). Vitam. \& Horm. 5, 175.

Porter, G., Lane-Petter, W. \& Horne, N. (1963). J. Anim. Tech. Ass. 13, 75.

Wooley, D. W. (194I). F. biol. Chem. r39, 29. 